\title{
The Impacts of VLJs on Tennessee Airports: A Case Study
}

\author{
C. Daniel Prather and Joseph C. Hawkins \\ Middle Tennessee State University
}

\begin{abstract}
In an effort to determine the level of preparedness among Tennessee general aviation (GA) airports for accommodating and servicing Very Light Jets (VLJs), a survey was conducted to determine if managers of Tennessee's GA airports feel their operations are adequately prepared to support the anticipated increase in aircraft movements and on-demand services related to the introduction of this new class of aircraft. The study investigated the perceptions of airport executives concerning the emerging VLJ market, and efforts undertaken to both prepare and promote general aviation airports in Tennessee as viable destinations for the VLJ operator. The paper highlights the VLJ movement (including the background of VLJ development), discusses the projected benefits of VLJs to local Tennessee communities not serviced by commercial air carrier service, and presents results of the survey. The study concludes by presenting several practical recommendations that governmental leaders and airport managers may use to justify improvements and expansion projects aimed at marketing general aviation airports across the state of Tennessee as important destinations for VLJs.
\end{abstract}

\section{INTRODUCTION}

Long before it became an economically viable product, the airplane was envisioned by aviation pioneers as the one machine that would shrink the world and bring the human race closer through the friendly exchange of cultures. This evolution continues today with the introduction of a new category of turbine powered aircraft: Very Light Jet (VLJ). As a class, VLJs incorporate significant advances in airframe design, powerplants, computerized avionics, materials and manufacturing techniques. These advances result in VLJs being less expensive to obtain and operate, certificated to be operated by a single pilot, and capable of operating into GA airports in smaller communities that previously were not able to safely accommodate larger corporate class jet aircraft.

The Federal Aviation Administration predicts that perhaps as many as 5,000 VLJs will be flying by the year 2016 (Sabatini, 2006). To put the potential impact of VLJs into perspective, in its annual industry delivery and shipment report, the General Aviation Manufacturers Association (GAMA) estimates there are only about 15,000 business jets of various weight and performance classes operating worldwide (GAMA, 2006). Even if considered as a conservative estimate of a few thousand aircraft, the manufacturing and support of VLJs represent a significant growth factor in the aerospace industry.

VLJ manufacturers agree with Federal Aviation Administration forecasts, expressing a shared optimism that an expanding world economy will produce an increasing number of wealthy individuals and business entrepreneurs who will demand utility, comfort and flexible aviation options (Polek, 2006). General aviation organizations such as the National Business Aviation Association (NBAA) anticipate a dynamic shift in corporate aviation with the introduction of VLJS. In a press release, Ed Bolen, President of the NBAA recently stated:

The development of VLJ aircraft is good news on many levels. Their introduction produces high-skill manufacturing jobs. They will help make many small and midsized companies more competitive, and they will strengthen aviation services for many small communities. Those benefits should be the focus of discussion about VLJs (Bolen, 2006, para 5).

Leading aviation conglomerates such as Honeywell Aerospace and Rolls-Royce predict a strong business jet market for at least the next decade during which general aviation manufacturers will distribute 12,000 airplanes worth an estimated \$195 billion. Rolls-Royce, a leading turbine engine supplier, anticipates that 
the VLJ niche will be responsible for a third of these new aircraft delivered. A major supplier of avionics and system components, Honeywell Aerospace calculates that VLJ assembly lines will produce about 250 airframes annually (Polek, 2006).

\section{VLJs DEFINED}

While the VLJ idiom may be new to many, the private jet concept certainly is not. The first personnel size business jet was envisioned in the early 1960 s by the renowned innovator Bill Lear. Introduced in 1964, the Lear 23 was the first successful small jet aircraft when it entered mass production. The original Model 23 was a seven-passenger, pressurized jet that flew at a top speed of 564 miles per hour with a range of 1,875 miles. The Lear 23 was a commercial success and led to the development of a number of new models with increased size, range and speed (Boyne, 1987).

Although small jet aircraft are not new to the world of aviation, the VLJ is considered innovative in many ways. Specifically, VLJs are turbine powered aircraft with a take-off weight of 10,000 pounds or less and certificated for single pilot operations (NBAA, 2005). VLJs will offer four to nine passenger seats, cruise speeds around 400 miles per hour and an operating range between 1,100 to 2,300 miles (George, 2005). Along with modern turbine engine technologies, these next generation light jet aircraft incorporate highly integrated avionics, along with advanced cockpit automation, refined passenger amenities and simplified aircraft systems designed to reduce pilot workloads.

The emerging VLJ market represents a new breed of general aviation aircraft and the beginning of a new niche of personnel air transportation and private jet charter. The operating parameters of most VLJ models afford little difference between a 10,000 pound maximum takeoff weight (MTOW) VLJ, a popular cabin-class turboprop aircraft such as a Raytheon King Air model, or heavier corporate aircraft. However, VLJs will afford slower approach speeds than most turboprops and several models will be capable of operating at the higher extremes of controlled airspace. Reduced weight resulting in slower approach speeds allows operations at more than 5,000 general aviation airports around the U.S. with paved runways 3,000 to 5,000 feet in length (NBAA, 2005).

The VLJ era is being ushered in by numerous aircraft manufacturers in various stages of development and competition. These varied manufacturing and design activities around the globe fuel an exciting period in the general aviation industry. This growth is spurred by a sustained demand for corporate class aircraft that allows determined travelers to avoid congested airport terminals and lengthy security screening queues, while realizing low operating costs and timely point-to-point service. As a consequence of a generally strong economy and favorable tax incentives, potential aircraft owners are seriously considering VLJs. The price of this new class of aircraft ranges from $\$ 1.0$ million to $\$ 3.5$ million, placing them well within the reach of many small, but emerging businesses, jet charter operators and moderately wealthy individuals (Phillips, 2006).

At the time of this research, there were no less than eight companies manufacturing VLJs. The following is a brief summary of VLJs that have either recently entered service or are expected to do so in the near future (specifications summarized in Table 1).

\section{Eclipse 500}

The Eclipse 500 was the first VLJ to receive provisional FAA type certification (Phillips, 2006). With an advertised range of nearly 1,400 miles, it can seat six passengers. The Eclipse VLJ is powered by two Pratt and Whitney PW610F mediumbypass turbofans that produce 900 pounds of thrust each. The Eclipse is able to operate from 3,400 foot long runways and cruise at 370 knots at a maximum service ceiling of 41,000 feet. Eclipse Aviation delivered its first customer aircraft on December 31, 2006, at its headquarters in Albuquerque, New Mexico. According to company officials, the manufacturing and support facilities at Eclipse Aviation are designed to produce 1,000 aircraft annually, and the company has an order backlog for more than 
2,500 aircraft costing about 1.5 million dollars each (Trautvetter, 2006).

\section{Cessna Mustang}

The Cessna Mustang is credited with many "firsts." Specifically, the Mustang was not only the first of the VLJ class to receive full type certification, but also the first to receive certification for flight into known-icing conditions, and the first VLJ to be delivered to a customer. The Cessna Aircraft Company said it expects to deliver about 40 Mustangs in 2007 with a price of about 2.4 million dollars per airframe. The Mustang is powered by two Pratt \& Whitney Canada PW600 turbofans producing 1,460 pounds of thrust each. It is configured for six seats and has a balanced field length of only 3,110 feet (George, 2006).

\section{HondaJet}

After nearly 15 years in development, Honda announced at AirVenture 2006 in Oshkosh that it would produce the Hondajet commercially. It plans to produce 70 aircraft per year at its new 250,000 square foot facility and hangar at Piedmont Triad International Airport in Greensboro, North Carolina, and has begun accepting orders for its VLJ entry through Piper aircraft dealers. An all-composite fuselage, the Hondajet is powered by two General Electric Honda HF120 turbofan engines, each rated at 1,880 pounds take-off thrust. Priced at 3.6 million dollars, the Hondajet is easily recognized by its unique over-the-wing engine mount configuration. According to Honda, this design eliminates the fuselage structure necessary to support engines, resulting in significantly reduced cabin noise and vibration, a larger cabin size and lower risk of engine damage resulting from the ingestion of foreign objects from tarmacs and runways. Takeoff distance for the HondaJet is estimated to be 3,120 feet over a 35 foot obstacle (Thruber, 2006).

\section{Adams Aircraft A700}

The A700 is the turbine-powered derivative of the piston engine A500. The new AdamJet will use the same wing, boom, tail, nose gear, instrument panel and comparable interior level and cabin seats as the A500. Unlike the Cessna Mustang and Eclipse 500, the AdamJet will be powered by Williams FJ-33 engines that produce 1,200 pounds of thrust each. Beginning in the summer of 2006, the A700 VLJ was in the midst of flight tests and development, and the company expected its VLJ to enter the marketplace sometime in 2008, costing about $\$ 2.25$ million each. It has also been reported that the company has more than 85 confirmed orders for the A700. The A700 will be powered by the Williams FJ33 turbine that was certified in 2004 and is a slightly less powerful version of the company's FJ44 engine that currently powers the Cessna Citation CJ1 and Raytheon Premier (Trautvetter, 2006).

\section{Embraer Phenom 100}

Developed by the Brazilian aircraft manufacturer Embraer, the Phenom cabin is designed for 4 passengers with a flying range of 1,160 nautical miles. Its price is estimated at $\$ 2.85$ million. The Phenom is expected to make its first flight mid-2008 with first deliveries beginning in 2010. It has been reported that the Phenom 100 will the most expensive VLJ on the market; nevertheless, Embraer is convinced that, in addition to the aircraft's performance, the elevated cabin amenities and passenger comfort features will serve as a distinction for this aircraft and be a significant selling point. The interior of the aircraft is being designed by BMW, and the Phenom 100 is the car manufacturer's first venture into the aircraft industry. The Phenom 100 will be powered by Pratt \& Whitney Canada PW617F engines, with 1,615 pounds of thrust each and expected to achieve a maximum operating speed of Mach 0.7 at 41,000 feet (Trautvetter, 2006).

\section{GENERAL AVIATION AIRPORTS: THE FRONT DOOR OF COMMUNITIES}

The most amazing aspect of air transportation is that it has become so important to our economy, defense, and social wellbeing in such a short time. Today, in cities and towns across the country, the local airport has developed into one of a community's greatest assets for economic and community development. Regardless of its size or number of flight operations, an airport directly impacts the local economy and overall strengths in the community it serves. Airports are major 
economic factors locally, not just by providing a variety of direct employment opportunities, but also through the creation of opportunities through the aircraft service sector. Local airports are excellent representatives of their community and often provide the first and perhaps only impression of the community to air travelers (Tennessee, 2005).

Table 1. VLJ Specifications

\begin{tabular}{|c|c|c|c|c|c|}
\multicolumn{2}{c}{} & \multicolumn{1}{l}{ VLJ Specifications } \\
\multicolumn{2}{c}{ MTOW } & $\begin{array}{l}\text { Landing } \\
\text { Distance }\end{array}$ & Range & Max Cruise & Cost \\
\hline Eclipse 500 & 5,920 & $2,250 \mathrm{ft}$. & $1,125 \mathrm{~nm}$ & $370 \mathrm{kts}$ & $\$ 1.52 \mathrm{M}$ \\
\hline Cessna Mustang & 8,645 & $2,380 \mathrm{ft}$. & $1,150 \mathrm{~nm}$ & $340 \mathrm{kts}$ & $\$ 2.39 \mathrm{M}$ \\
\hline Adam A700 & 8,500 & $2,520 \mathrm{ft}$. & $1,200 \mathrm{~nm}$ & $340 \mathrm{kts}$ & $\$ 2.25 \mathrm{M}$ \\
\hline Honda Jet & 9,200 & $2,500 \mathrm{ft}$. & $1,180 \mathrm{~nm}$ & $420 \mathrm{kts}$ & $\$ 3.65 \mathrm{M}$ \\
\hline $\begin{array}{c}\text { Embraer Phenom } \\
100\end{array}$ & TBD & $3,000 \mathrm{ft}$. & $1,160 \mathrm{~nm}$ & $380 \mathrm{kts}$ & $\$ 2.85 \mathrm{M}$ \\
\hline
\end{tabular}

Notes: MTOW refers to maximum takeoff weight in pounds. Data based on NBAA IFR reserves (35 min) with $100 \mathrm{~nm}$ alternate; 4 occupants @ 200lb. Adapted from "Your Window on the Emerging World of VLJs," (2007); "Eclipse 500 Compared to Other Aircraft," (2007).

Tennessee is fortunate to have a welldeveloped air transportation system consisting of six commercial service airports offering scheduled airline passenger service, 14 regional airports specifically designed to support high performance general and corporate class aircraft, and 55 smaller general aviation airports designed to meet the general aviation wants of local aviation enthusiasts (Tennessee, 2005). This current status evolves from efforts in the early $1920 \mathrm{~s}$ by the Tennessee legislature enacting the first of a series of aviation acts promoting aviation, airways and airport development (Fulbright, 1996). These efforts continue today, through the Aeronautics Division of the Tennessee Department of Transportation which provides engineering and construction support, grant procurement and educational assistance to communities across the state (Fulbright, 1996, p.146).

Beech River Regional Airport in Darden, Tennessee is the newest regional general aviation facility built in Tennessee in over 20 years. Opened on May 25, 2006, Beech River replaced two smaller local airports deemed obsolete and too expensive to enhance to meet current and future demands. Beech River was intentionally designed and built to attract business and industrial prospects. With a concrete-paved 6,000 foot long runway and 100 foot wide full length concrete-paved parallel taxiway, Beech River Regional Airport is ideally suited for VLJ operations and heavier corporate aircraft such as the Gulfstream V (Decatur County, 2006). Tennessee is also the corporate home of Federal Express Corporation (FedEx), the world's largest express freight transportation company. FedEx operates its principal overnight package sorting facility at the Memphis International Airport and has consistently been the international leader for total air cargo handled since 1992 (Airports Council International, 2006).

\section{METHODOLOGY}

\section{Purpose}

In designing this research effort, the authors desired to determine both the current status of the VLJ industry and the degree to which Tennessee airports were prepared to meet the needs of this new class of jet aircraft. In essence, as the VLJ will likely introduce jet operations to airports which previously had no or very few jet operations, our goal was to determine if these airports were prepared for 
VLJs, and if not, what plans had been adopted to become better prepared. To conduct this study, two methods were selected. First, a review of literature on this topic was conducted to gain insight into the VLJ market, the VLJ manufacturers, and potential demand. Second, to determine the level of preparedness of Tennessee general aviation airports in accommodating VLJs, a survey research effort was undertaken.

The results of this study should prove important for Tennessee airport managers, Tennessee communities, VLJ manufacturers, potential VLJ customers, and the State of Tennessee Division of Aeronautics. In essence, by providing insight into the level of preparedness of general aviation airports throughout the state of Tennessee and the manner in which these airports are better preparing to meet the needs of VLJs, the study results will allow these stakeholders to better anticipate and plan for the introduction of VLJs into the Tennessee aviation system, and make adjustments to marketing plans, airport master plans, and other airport-specific programs and objectives.

\section{Participants}

The focus of this research effort was airports throughout the state of Tennessee. This population was selected as a matter of convenience, as both authors currently reside in this state and are more familiar with the airports and airport managers located throughout this state. According to the most recent Tennessee Airport Directory (Tennessee Department of Aeronautics, 2003), the State of Tennessee currently has 81 public-use airports. Six of these airports are commercial-service airports and were excluded from this study (Chattanooga, Jackson, Knoxville, Memphis, Nashville, and Tri-Cities). The remaining 75 airports were included in this study.

Utilizing the State of Tennessee Division of Aeronautics Tennessee Airport Directory, supplemented with phone calls as necessary to confirm e-mail addresses, the entire population of 75 public-use general aviation airports throughout the state of Tennessee was selected for this study. As all contact with participants was planned via email, the email addresses for airport managers at each of these airports was entered into a database.

\section{Survey Instrument}

The authors designed an original questionnaire for this study (Appendix A). Utilizing Survey Monkey, an on-line survey website, a nine-item questionnaire was designed. The questionnaire focused not only on the current facilities and services available at these airports, but also the anticipated impact of VLJs, and the level to which each airport was currently prepared to accommodate VLJs. If an airport indicated they were either currently "unprepared" or "very unprepared" to meet the needs of VLJs, they were directed to two additional questions (using SurveyMonkey's question logic) that asked how well prepared they would be within the next three years, and what plans they had to become better prepared. Lastly, the questionnaire asked respondents to explain what potential problems would be experienced with the introduction of VLJs into the Tennessee airport system and to recommend ways in which to address these problems.

\section{Procedure}

This study, which was conducted from November 2006 to January 2007, began with an email invitation to the entire population of 75 airport managers on November 13, 2006. Included in the email was an electronic link to the on-line survey. The email introduced the survey and explained the importance of the research effort. Per SurveyMonkey policy, a link was also included to allow individuals the opportunity to decline participation in the survey and discourage future follow-up by the researcher.

In determining the completed sample size necessary for valid results, Dillman (2000) was consulted. Utilizing his formula, and allowing for $+/-10 \%$ sampling error with an estimated $80 / 20$ split answer variability at the 95 percent confidence level, the completed sample size needed for this desired level of precision was 34 .

A total of nine emails were returned as undeliverable, which required additional phone calls to determine correct email addresses. With correct email addresses, these airport managers were then sent the email containing the survey link. As of November 21, a total of 20 survey 
responses had been received. A reminder email was sent to all non-respondents on November 21. By year-end, a total 35 responses had been received, which equated to a 46.6 percent response rate and satisfied the desired completed sample size previously determined.

\section{Limitations}

Due to the inclusion of only airports throughout the state of Tennessee, this study is limited in that conclusions drawn from the results can only be attributed to airports in this state. However, the authors plan to conduct future research on this topic to include airports nationwide.

\section{RESULTS}

\section{Runway lengths}

One benefit of VLJs is the short runway length required for takeoff, compared to many other turbine-powered aircraft. In fact, all of the VLJs previously discussed are able to take off (at sea level) in distances between 2,297 and 3,400 feet. Thus, if an airport does not have runways of this minimum length, it becomes apparent that such an airport is not currently prepared to accommodate these jets. Item one asked participants, "What is the length of your airport's longest paved runway?" All respondents indicated their longest paved runway was at least 3,000 feet, with 31 respondents (88.6) percent indicating a runway of at least 3,500 feet. Thus, it appears from those responding airports that lack of runway length will not prevent the accommodation of at least some types of VLJs.

\section{Airport services}

Airport managers were also asked about the services currently provided either by their airport or an FBO located on their airport. See Figure 1 for an indication of their responses. Of particular interest to VLJ operators, although 80 percent of responding airports have at least one hangar and over 90 percent have ramp parking and tie-downs, approximately 90 percent do not have de-icing capability, 30 percent do not have an instrument approach, 30 percent do not sell Jet A fuel, 25 percent do not have an on-field
FBO, 55 percent do not have a power cart, 35 percent do not have security (in the form of Airport Watch, security guard, or Security Plan), 70 percent do not have a turbine-aircraft maintenance run-up area, and 70 percent do not have turbine maintenance and/or repair services. Thus, while each of these services is offered in some form at some of the responding airports, it appears that airports wishing to attract VLJs in the future and offer a high level of customer service, will need to invest in these additional services (such as Jet A fuel and turbine maintenance services).

\section{Anticipated demand}

Although industry is predicting a great influx of VLJs into the aviation system in the near future, the researchers of this study felt it important to ask airport managers how they felt about this anticipated demand. Respondents were asked "How likely do you feel it is that at least one VLJ will begin utilizing your airport on a regular basis within the following time periods?" (See Table 2.) Clearly, over half of respondents are fairly confident that at least one VLJ will begin utilizing their airport within one year. Seventy-five percent are confident that they will begin seeing a VLJ on a regular basis 1 to 2 years from today. Almost 85 percent of respondents expect to see regular VLJ operations at their airport more than two years from today.

\section{Level of preparedness}

When asked how prepared their airport is currently to meet the needs of VLJs, 34 percent indicated they were very prepared, 37 percent indicated they were prepared, 23 percent indicated they were unprepared, and 6 percent indicated they were very unprepared. Thus, although it is positive to see that over 70 percent feel prepared to some degree, almost 30 percent of responding airport managers feel their airport is not prepared to meet the needs of VLJs.

As a follow-up question to those airports not prepared to accommodate VLJs, airports were asked how well prepared they would be within the next three years to meet the needs of VLJs. 


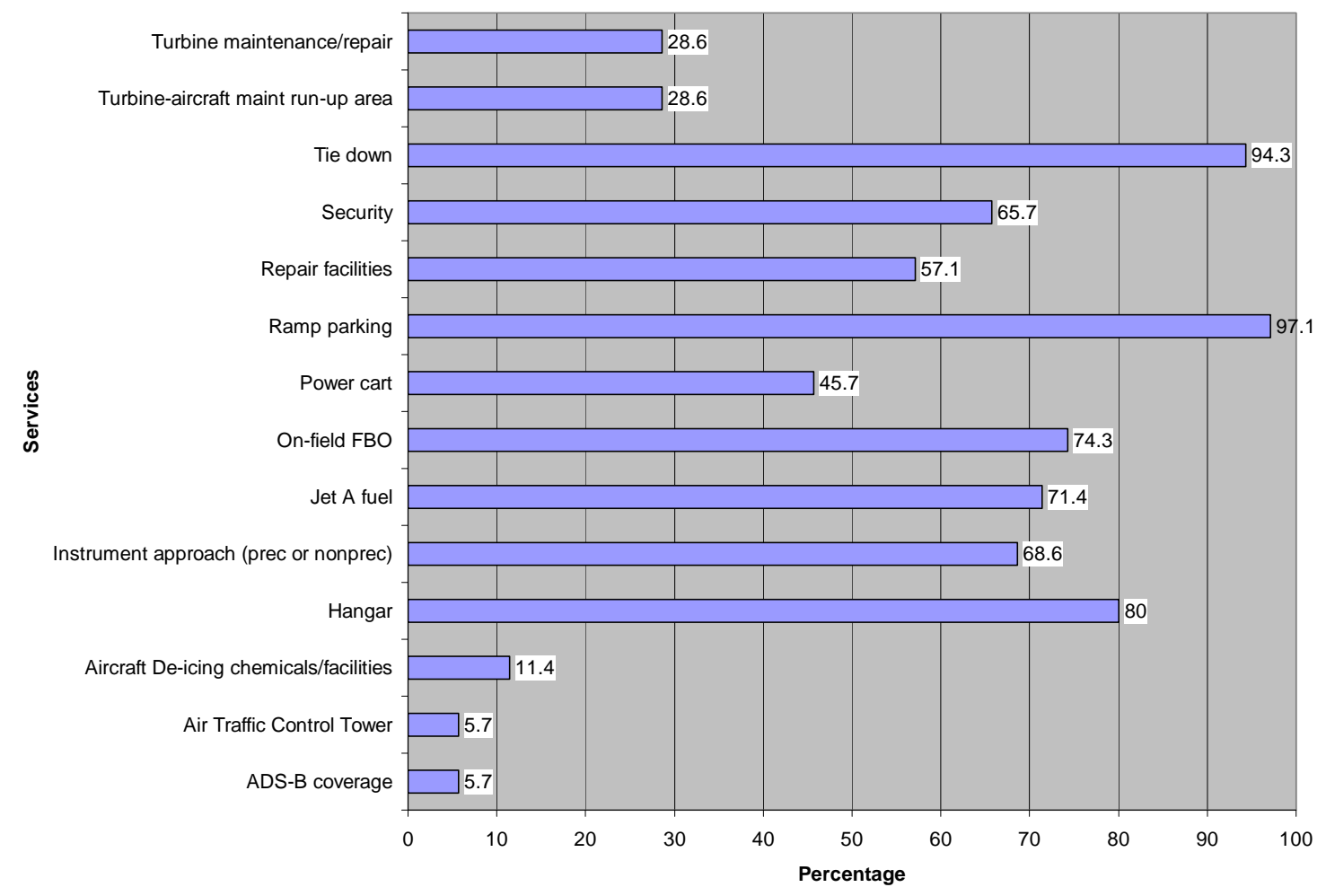

Figure 1. "Which of the following services are available at your airport?

Table 2. "How likely do you feel it is that at least one VLJ will begin utilizing your airport on a regular basis within the following time periods?"

\begin{tabular}{|l|l|l|l|l|}
\hline & Very Likely & Likely & Unlikely & Very Unlikely \\
\hline $\begin{array}{l}\text { Less than 1 year from } \\
\text { today }\end{array}$ & $35 \%(9)$ & $19 \%(5)$ & $19 \%(5)$ & $27 \%(7)$ \\
\hline $1-2$ years from today & $32 \%(9)$ & $43 \%(12)$ & $18 \%(5)$ & $7 \%(2)$ \\
\hline $\begin{array}{l}\text { More than 2 years from } \\
\text { today }\end{array}$ & $33 \%(7)$ & $52 \%(11)$ & $5 \%(1)$ & $10 \%(2)$ \\
\hline
\end{tabular}

Note: Number of responses in parentheses.

Although 40 percent indicated they would be prepared, 60 percent indicated they would still be unprepared to meet the needs of VLJs within the next three years. This finding should be of concern to VLJ manufacturers, as well as potential VLJ operators. In essence, with a number of Tennessee airports unprepared to handle VLJs, these airports should not be considered as viable destinations for VLJ operators. Clearly, this should be of concern to these airports, as well as the entire Tennessee airport system.

\section{Future plans}

To determine what "unprepared" airports are doing to become prepared, the questionnaire asked airport managers to detail their airport's future plans to become better prepared to meet the needs of VLJs. Nine airport managers responded to this question by offering the comments detailed in Table 3.

It is indeed interesting to see what future plans these airports have to better meet the needs of VLJs. Although two airports have no plans for improvements, the majority are moving in the right direction to become well prepared to meet the needs of VLJs.

\section{Potential problems}

Lastly, survey participants were also asked if they could foresee any potential problems associated with the introduction of VLJs into the 
Table 3. For those airports currently unprepared to meet the needs of VLJs, "What are your airport's future plans to become better prepared to meet the needs of VLJs?"

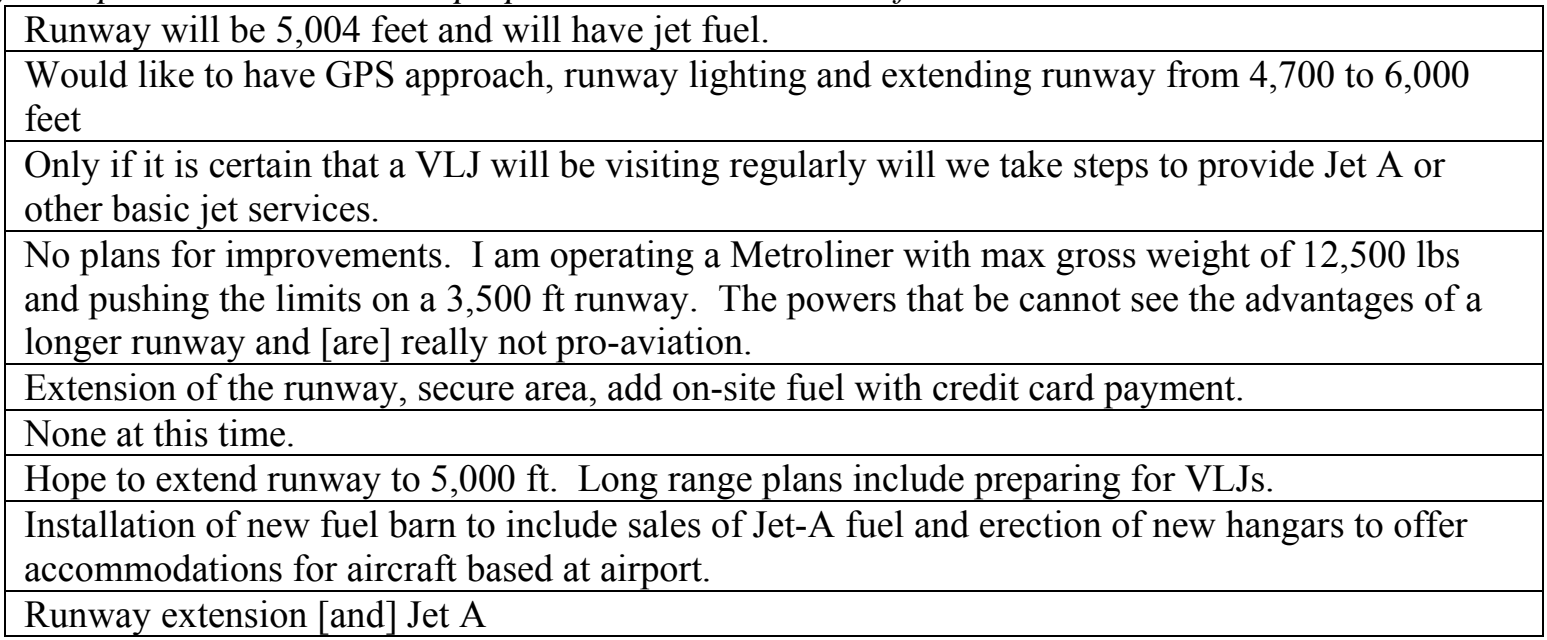

Tennessee airport system. The vast majority, 97 percent, could see no problems. However, one airport manager expressed concerns similar to those voiced by the National Air Traffic Controllers Association. This respondent predicted "airspace saturation due to low performance capabilities of these jets (VLJs) versus airliner type aircraft." This individual further explained that "at [the] present time, the regional jets (such as CRJ's and EMB's) 'clog' the jet airways with their slow airspeed and impede [larger air carrier] aircraft from achieving optimal cruise flight speeds." To counteract this tendency of becoming "an obstruction to orderly traffic flow," this respondent suggests that the FAA mandate "that ATC controllers restrict their altitude or require that they fly off jet airways while above FL240 if traffic demands deem appropriate."

Although these VLJs are generally able to fly at maximum cruise speeds of 315 to 380 knots, there are predictions that they will "clog" the airways and interfere with commercial jet traffic. However, the FAA has attempted to quiet these fears by assuring the aviation community that measures are in place to prevent VLJs from becoming a burden on the national air transportation system. In fact, Nicholas Sabatini, FAA associate administrator for aviation safety, assured the Senate Commerce Committee in September 2006 that, "The system is in place today to accommodate the entry of new aircraft into the National Airspace
System...this is nothing new for the FAA. It is our day-to-day business" (AAAE, 2006, para. $5)$. Whether this is true remains to be seen.

\section{DISCUSSION AND RECOMMENDATIONS}

As can be seen, this study of Tennessee airport managers resulted in a great deal of insight into the study's goal of determining if Tennessee airports are adequately prepared to accommodate VLJ aircraft at their facility. First, lack of available runway length will not, in general, prevent a VLJ from utilizing a particular airport. All survey participants reported runway lengths of at least 3,000 feet. This is sufficient to handle many of the VLJs highlighted in this paper, which typically require 2,300 to 3,400 feet for takeoff at sea level.

Second, although many responding airports do have the basic services necessary to service a VLJ, approximately $1 / 3$ of responding airports do not have an instrument approach, Jet A fuel, an on-fuel FBO, or security (in the form of Airport Watch, security guard, or security plan). Plus, less than 30 percent of responding airports have a turbine aircraft maintenance run-up area or turbine maintenance and/or repair services. Does this mean that these airports will not be able to accommodate a VLJ? No, it does not. However, it does mean that the airport will not be able to offer a level of service that VLJ operators will expect. In essence, at $1 / 3$ of these airports, a VLJ can fly in and land. But, they cannot land in instrument weather conditions, 
purchase fuel, be assured of security while their multi-million dollar aircraft is at the airport, or receive turbine maintenance and/or repair services. This simply means that approximately $1 / 3$ of Tennessee general aviation airports (if survey results are representative of the population), may be viewed as unable to serve VLJs, due these lack of services. This will negatively impact the communities that hope to attract new aircraft operations by these new generation jets, in terms of lost revenue, and lost aircraft operations.

Third, it is interesting to note that approximately $1 / 3$ of responding airports feel unprepared to meet the needs of VLJs. This confirms the study findings discussed in the previous paragraph. Interestingly, there is also a group of airports ranging from between 46 percent to 15 percent that feel it is unlikely that at least one VLJ will begin utilizing their airport in either less than one year, 1 to 2 years, or more than 2 years from today. It seems plausible, therefore, that the group of airports both lacking jet services and feeling unprepared to handle VLJs, is a group of airports that also feel it is unlikely their airport will even see a VLJ on a regular basis in the near future. Although it is not possible to determine if the same airports responded in the same way to these questions, it is possible that these unprepared airports are unprepared because they see no need to become prepared; in essence, considering it unlikely that at least one VLJ will begin utilizing their airport in the near future. If this finding proves true, it should be of little concern to Tennessee airports. However, the researchers conducting this study are both familiar with Tennessee airports and the requirements of VLJs. It would seem that all general aviation Tennessee airports should be prepared to accommodate VLJs, or else the fact some are unprepared would become a selffulfilling prophecy in which VLJs do not serve those airports because they are not adequately prepared.

As such, the researchers believe it is prudent for all Tennessee general aviation airports to develop plans to accommodate VLJs in the near future. At a minimum, these plans should include improvements to security and safety operations that will appease the discriminating owner of this new class of corporate aircraft. To accommodate increased aircraft operations and the more sophisticated needs of turbine powered aircraft, airport managers and governing authorities should give serious consideration to adding new runways or extending existing runways and incorporating high speed taxiways to safely and expeditiously handle VLJs. Tennessee airports that currently do not offer jet fuel, heated hangers or maintenance services should begin the process to secure these conveniences as quickly as possible to maximize their marketability as the VLJ fleet grows. Upgrading physical facilities such as terminal buildings, flight planning rooms, restrooms and lounges will also be an important tool for attracting and retaining significant VLJ operations.

\section{CONCLUSION}

The Beech River Regional Airport, like many other general aviation airports in Tennessee, serves as an important link for businesses operating in the state and as a reliever airport for the larger commercial airports. These general aviation airports are a key component of the state's transportation system and must be kept up to date, not only to support the airport's continued growth, but the economic viability of the local community as well.

If predictions prove correct, the VLJ niche will be a strong market with lasting appeal. If these numerous forecasts are only partially correct, the nation's air transportation system could see the addition of thousands of new aircraft entering service in a very short time span. It is certain that a significant number of these airplanes will operate from general aviation airports and will require the services of Tennessee airports. While many airports in Tennessee indicate they are capable of handling VLJ aircraft and welcome the VLJ class as a unique marketing opportunity, a significant number are not prepared for a variety or reasons. Consequently, unless these under-prepared airports-increase their level of services soon and engage in a plan of action designed to attract new aircraft such as the VLJ, it is predictable that these communities will languish while others enjoy a significant level of growth, influence and prosperity. 


\section{APPENDIX A}

\section{Survey of Tennessee Airports on VLJ Preparedness}

\section{Consent}

The Airport Managers of all non-commercial service, General Aviation Airports throughout the state of Tennessee are invited to participate in this study to determine the level of preparedness among Tennessee Airports to accommodate VLJs. There are no known risks if you choose to participate, nor will you be penalized if you decide not to participate. There are no rewards (monetary or otherwise) available to those who choose to participate. By completing this on-line survey, you are voluntarily agreeing to participate. Your responses will remain confidential; neither you nor the Airport you represent will be identified in the study results. The questionnaire should take approximately 5 minutes to complete.

IRB \# 07-092

If you have any questions concerning your rights as a research subject, please contact:

Ms. Tara Prairie

Compliance Officer

Middle Tennessee State University

BAS S245

Murfreesboro, TN 37132

615-494-8918

compliance@mtsu.edu

If you have any questions about this study, please contact either:

C. Daniel Prather, A.A.E.

Associate Professor

Department of Aerospace

Middle Tennessee State University

Box 67

Murfreesboro, TN 37132

615-898-2289

dprather@mtsu.edu

Or

Joe Hawkins

Assistant Professor

Department of Aerospace

Middle Tennessee State University

Box 67

Murfreesboro, TN 37132

615-904-8360

jhawkins@mtsu.edu

\section{Thank you for your time!}


For the purpose of this study, VLJ refers to Very Light Jets. VLJs are generally defined as technologically advanced, high-performance turbine-engine-powered aircraft weighing 10,000 pounds or less (maximum certificated takeoff weight) and certificated for single pilot operations. Examples of VLJs include the Eclipse 500, Cessna Mustang, Adam 700, Embraer VLJ, Epic LT, HondaJet, and D-Jet.

1. What is the length of your airport's longest paved runway?

\begin{tabular}{|c|l|}
\hline$\square$ & Less than 2,400 feet \\
\hline$\square$ & At least 2,400 feet, but no more than 3,000 feet \\
\hline$\square$ & At least 3,000 feet, but no more than 3,500 feet \\
\hline$\square$ & At least 3,500 feet \\
\hline
\end{tabular}

2. Which of the following services are available at your airport?

\begin{tabular}{|c|l|}
\hline$\square$ & ADS-B coverage \\
\hline$\square$ & Air Traffic Control Tower \\
\hline$\square$ & Aircraft De-icing chemicals and/or facilities \\
\hline$\square$ & Hangar \\
\hline$\square$ & Instrument approach (precision or non-precision) \\
\hline$\square$ & Jet A fuel \\
\hline$\square$ & On-field FBO \\
\hline$\square$ & Power cart \\
\hline$\square$ & Ramp parking \\
\hline$\square$ & Repair facilities \\
\hline$\square$ & Security (Airport Watch, security guard, or Security Plan) \\
\hline$\square$ & Tie-down \\
\hline$\square$ & Turbine-aircraft maintenance run-up area \\
\hline$\square$ & Turbine maintenance and/or repair services \\
\hline
\end{tabular}

3. How likely do you feel it is that at least one VLJ will begin utilizing your airport on a regular basis within the following time periods?

\begin{tabular}{|l|c|c|c|c|}
\hline & $\begin{array}{c}\text { Very } \\
\text { Likely }\end{array}$ & Likely & Unlikely & $\begin{array}{c}\text { Very } \\
\text { Unlikely }\end{array}$ \\
\hline Less than 1 year from today & $\square$ & $\square$ & $\square$ & $\square$ \\
\hline 1-2 years from today & $\square$ & $\square$ & $\square$ & $\square$ \\
\hline More than 2 years from today & $\square$ & $\square$ & $\square$ & $\square$ \\
\hline
\end{tabular}

4. Overall, how well prepared is your airport to meet the needs of VLJs?

\begin{tabular}{|c|c|c|c|}
\hline Very Prepared & Prepared & Unprepared & Very Unprepared \\
\hline$\square$ & $\square$ & $\square$ & $\square$ \\
\hline
\end{tabular}

*If answering "Unprepared" or "Very Unprepared" to Item 4, respondents were directed to items 5 and 6. If answering "Very Prepared" or "Prepared" to Item 4, respondents were directed to item 7.

5. How well prepared will your airport be within the next three years to meet the needs of VLJs?

\begin{tabular}{|c|c|c|c|}
\hline Very Prepared & Prepared & Unprepared & Very Unprepared \\
\hline$\square$ & $\square$ & $\square$ & $\square$ \\
\hline
\end{tabular}


6. What are your airport's future plans to become better prepared to meet the needs of VLJs?

7. Based on your professional expertise and experience, do you foresee any potential problems with the introduction of VLJs to the Tennessee airport system?

\begin{tabular}{|l|l|}
\hline$\square$ & Yes \\
\hline$\square$ & No \\
\hline
\end{tabular}

*If answering "Yes" to item 7, respondents were directed to items 8 and 9. If answering "No" to item 7 , respondents were directed to end of questionnaire

8. Specifically, please explain what potential problems you foresee with the introduction of VLJs to the Tennessee airport system.

9. How would you recommend these potential problems be addressed?

\section{Thank you very much for your time and effort in completing this questionnaire!}

Please contact either of us with any comments.

C. Daniel Prather, A.A.E.

Associate Professor

Department of Aerospace

Middle Tennessee State University

Box 67

Murfreesboro, TN 37132

615-898-2289

dprather@mtsu.edu

Or

Joe Hawkins

Assistant Professor

Department of Aerospace

Middle Tennessee State University

Box 67

Murfreesboro, TN 37132

615-904-8360

jhawkins@mtsu.edu 


\section{REFERENCES}

Airports Council International. (2006, July 17). Yearly cargo traffic report: Cargo traffic final 2005. Retrieved December 11, 2006, from http://www.airports.org/cda/aci/display/main /aci_content.jsp?zn=aci\&cp=1-554-190_9_2_

American Association of Airport Executives. (2006, September 28). FAA predicts 5,000 VLJs flying by 2017. Retrieved September 28, 2006 from ANTN Digicast Aviation News.

Bolen, E. (2006, October 1). Press Release. National Business Aircraft Association.

Bolen blasts ATA for unfounded comments on VLJs. Retrieved October12, 2006, from http://web.nbaa.org/public/news/pr/2006/20061002-042.php

Boyne, W. J. (1989). The Smithsonian book of flight. New York: Orion.

Decatur County. (2006, May 25). Mayor Broadway announces opening of new Beech River airport. Retrieved February 11, 2006, from http://www.decaturcountytn.org/articles/ Opening_of_New_Beech_River_Airport.asp

Dillman, D. A. (2000). Mail and internet surveys: The tailored design method. New York: John Wiley \& Sons.

Eclipse 500 compared to other aircraft. (2007). Retrieved April 8, 2007, from http://www.eclipseaviation.com/files/pdf/ComparedChart.pdf.

Fulbright, J. (1996). The Aviation History of Tennessee. Smyrna, TN: Courier.

General Aviation Manufacturers Association. (2006, February 6). GAMA international shipment report 2005end-of-year. Retrieved October 11, 2006, from http://www.gama.aero/mediacenter

George, F. (2006, October). Citation Mustang. Business and Commercial Aviation, 99, 76-85.

George, F. (2005, January). A new deal in business jets. Business and Commercial Aviation, 96, 36-42.

National Business Aircraft Association. (2005, November). NBAA training guidelines for single pilot operations of VLJs and technically advanced aircraft. Washington, DC: Author.

Phillips, E. H. (2006, October 16). Bizjets are hot. Aviation Week and Space Technology, 165, 58-61.

Polek, G. (2006, November). Forecasts predict boom for bizav. Aviation International News, 38, 14.

Spectrum (n.d.). Spectrum independence competitive analysis. Retrieved April 5, 2007 from http://www.spectrum.aero/media/Spectrum_Independence_Specs.pdf.

State of Tennessee, Department of Transportation. (2005, January). Tennessee long-range transportation plan: Aviation system plan update final report. Author.Sabatini, N. A. (2006). Statement of Nicholas A. Sabatini, Associate Administrator for Aviation

Safety Before the Committee on Transportation and Infrastructure, Subcommittee on Aviation, on FAA Safety Oversight. Retrieved November 9, 2006, from http://www.faa.gov/news/testimony/ news_story.cfm?newsId=7395

Tennessee Department of Aeronautics. (2003). Tennessee Airport Directory. Author.

Thurber, M. (November, 2006) Sales brisk for new HondaJet. Aviation International News, 38, 8.

Trautvetter, Chad. (October, 2006). New Bizjets. Aviation International News, 38, 20. Your window on the emerging world of VLJs. (2007). Retrieved April 8, 2007, from http://www.verylightjetmagazine.com/ jets/php 